\author{
S.N. Abashin ${ }^{1}$ (iD) , G.A. Meirmanova ${ }^{2 *(i)}$, K.B. Baudiarova ${ }^{2}$ \\ ${ }^{1}$ European University in St. Petersburg, Russian, St. Petersburg \\ ${ }^{2}$ Al-Farabi Kazakh National University, Kazakhstan, Almaty \\ *e-mail: meirmanovaga@gmail.com
}

\title{
STATUS OF THE KAZAKH BRIDAL: TRADITIONS AND MODERNITY
}

In the article, the author clearly describes the role and etiquette of brides in Kazakhstani society. Ethnocultural education of Kazakh brides has entered their daily life. This has been the case in nomadic society for centuries. In the morning, they show respect by welcoming their parents and doing their daily routines - making tea early in the morning, setting the table, serving tea, cleaning the house, cooking, milking cows, entertaining guests, farming, and so on. The tradition of greeting is the respect and greeting of brides to their parents and in-laws. She greetings to other family members too. The bridegroom bowed down to greet the bridegroom's relatives. Shemakes tea and sets the table. The one who greets the bride expresses her gratitude to the bride. The bride wears a scarf in front of adults. It is also respect to adults.Forgiveness, understanding, helping each other in difficult momentare the tips that lead to happiness. As they say, "from the very beginning, the wife, from the age of the child," the boy's mother and father pay great attention to the bride's behavior, ability to do something and character. Because the customs in each country are different.

Key words: etiquette, big house, shanyrak, mother-in-law.

\author{
С.Н. Абашин ${ }^{1}$, Г.А. Мейрманова ${ }^{2 *}$, Қ.Б. Баудиярова ${ }^{2}$ \\ ${ }^{1}$ Санкт-Петербургтегі Еуропалық Университет, Ресей, Санкт-Петербург қ. \\ 22л-Фараби атындағы Қазақ ұлттық университеті, Қазақстан, Алматы қ., \\ *e-mail: meirmanovaga@gmail.com
}

\section{Қазақ келіндерінің мәртебесі: дәстүр мен жаңашылдық}

Мақалада авторлар қазақ қоғамындағы келін әдебін зерттейді. Әр елдегі әдет-ғұрыптар әртүрлі. Авторлар қазақ келінінің әдеп ерекшеліктеріне назар аударып, оны басқа халықтармен салыстырады. Сондай-ақ, ерлі-зайыптылардың, келіндердің этикетіне және бала тәрбиесіне маңызды көңіл бөлінеді. Полигамия, ажырасу мәселелеріне қатысты мінез-құлық нормалары, сонымен қатар күнә, қылмыс және оларды шешу жолдары туралы дәстүрлі ұғымдар нақтырақ талданады. Авторлар қазақ қалыңдығының күнделікті өміріне енген этномәдени тәрбиесін сипаттайды. Бұл ғасырлар бойы көшпелі қоғамда болған. Таңертең олар ата-енесіне сәлем салып, ізет көрсетіп, күнделікті іс-әрекеттерді орындайды: таңертеңгілік ас дайындау, үйді тазалау, тамақ дайындау, сиыр сауу, қонақ қарсы алу, шаруашылықпен айналысу және т.б. Қазақ дәстүрінде келінге қатысты ең қатаң этикет нормалары бар. Жас келін шаңырақ табалдырығын оң аяқпен (бұл некенің сәтті басталғанын көрсетеді) аттағанынан бастап, отқа май құйып, күйеуінің жанұя мүшесі атанады. «Келінді босаға аттағаннан, баланы бесіктен бастап тәрбиелеу» дегендей ата-ене келінді отбасы заңдылықтарымен таныстырып, үй шаруашылығына бейімдейді.

Түйін сөздер: этикет, үлкен үй, шаңырақ, қайынене, отағасы.

\author{
С.Н. Абашин ${ }^{1}$, Г.А. Мейрманова ${ }^{2 *}$, К.Б. Баудиярова ${ }^{2}$ \\ ${ }^{1}$ Европейский университет в Санкт-Петербурге, Россия, г. Санкт-Петербург \\ ${ }^{2}$ Казахский национальный университет имени аль-Фараби, Казахстан, г. Алматы \\ *e-mail: meirmanovaga@gmail.com
}

\section{Статус казахской невестки: традиции и современность}

В статье авторы исследуют роль этикета невестки в казахстанском обществе. Обычаи в каждой стране разные. Авторы акцентируют внимание на особенности этикета каахской невестки, сравнивая ее с другими народами. Важное внимание также уделено этикету супругов, невестки и воспитанию детей. Освещены также поведенческие нормы, связанные с проблемами многоженства, развода, а также этническим осмыслением традиционных понятий о грехе, преступлений и способах их разрешений. Авторы описывают 
этнокультурное воспитание казахских невест, вошедшее в их повседневную жизнь. Так было в кочевом обществе на протяжении веков. Утром проявляют уважение, приветствуя родителей, и выполняют повседневные дела - заваривают чай рано утром, накрывают стол, подают чай, убирают в доме, готовят, доят коров, развлекают гостей, занимаются сельским хозяйством и так далее. В традиции казахов именно по отношению к невестке были разработаны наиболее жесткие этикетные нормы. Как только молодая переступала порог юрты мужа правой ногой (это предвещало благополучие в браке) и наливала масло в огонь, она становилась членом его семьи, рода. Как говорится, «с самого начала жена, с возраста ребенка», мать и отец мальчика уделяют большое внимание поведению невесты, умению заниматься хозяйством, воспитанию.

Ключевые слова: этикет, большой дом, шанырак, теща, конное расследование, глава семьи.

\section{Introduction}

Bride etiquette is a code of conduct that is an essential principle for the bride, who is exposed to a new environment after the wedding. The bride's house is a link of coexistence, which includes the qualities of dignity, politeness, decency, compactness, harmony, flexibility, morality, foresight, purity and strict adherence to the norms of kindness in society and the community, focuses on upbringing in accordance with moral norms.

Materials and methods. Using methods of field ethnographic research. The actions of Kazakh brides were carried out by the method of external observation; dialectical methods of cognition of natural phenomena and society were used as a methodological basis for the study. The research used general scientific and private historical methods. Among the general scientific methods were analysis, synthesis, logical methods. In the category of special-historical methods, historical-retrospective, historical-typological, historical-systematic methods can be distinguished.

Results and discussion. Before becoming a bride, she must be under the care of her mother andsister-in-law. Not only his family, but the whole village sympathizes her on the principle of "forty norms" and wishes her to settle down and become a good bride, contributes to good upbringing. (Abashin, 2001: 87). The upbringing of a bride in a new environment begins with the song "betashar", accompanying the rite of the blanket covered the face of the bride.

The "betashar" provides guidance on the bride's new life activities, behavior, attitudes, and relationships, as well as tips that will help her in her daily life(Meirmanova, 2009: 13) . Having been brought up by her parents, cousin, and village, the young bride, guided by the advice given at the "betashar", gets up earlyin the morningafter the wedding and opens"tundyk" of a big house which is called Kara Shanyrak, where her husband's parents live. Then she opens the "tundyk" of brothers-inlaw, and finally her own. In order to light a fire in the house, she goes to get firewood from a big house. Then, before performing duties, she greets parents in the morning with respectand does her daily chores such asmaking tea early in the morning, setting the table,tidying the house, cooking, milking the cows, livestock, and so on. etc. deals with peasants. She gets up early and goes to bed late In order to finish domestic chores on time.

Kazakh people say, "A good bride is like your daughter, and a good husband is like your son" (Argynbaev, 1962: 122).

The tradition of greeting is the respect and greeting of brides to their parents and in-laws. She greetings to other family members too. The bridegroom bowed down to greet the bridegroom's relatives. Shemakes tea and sets the table. The one who greets the bride expresses her gratitude to the bride. The bride wears a scarf in front of adults. It is also respect to adults.

It is better to give up bad behaviors when she becomes a bride. Does not speak rudely, does not behave rudely. If the clothes which she wears are pleasing to adults, it is also a gift to their parents and spouse. It is better to consult with them about what to do. To respect a spouse whether in public or in private, is a blessing to honor. Forgiveness, understanding, helping each other in difficult momentare the tips that lead to happiness.

As the saying goes, "from the beginning of the wife, from the age of the child", the boy's mother and father pay great attention to the bride's behavior, ability to do something and character. Because the customs of each country are different. Adapting a bride to a new environment requires a great deal of responsibility from the adults in the home. It depends on where the bride is. There exist saying: "A bride in a good house is a bride, and a bride in a bad house is a pestle. "According to the Kazakh tradition, a married man does not receive an inheritance immediately and he is not separated from the family he grew up in. For some time, they control the bride, and her mother and uncles told her about the responsibilities of the new bride, what she is supposed to do, what she said, and so on. Teaches and monitors. The advice of mothersin-law from the life experience is very important for 
the bride to fulfill her duties perfectly and contribute to the formation of a dignified, hard-working bride, a respectful mother, to be a good family in the future.

The bride also needs to know the basic qualities of her future husband:

- Character,

- habits,

- thought and culture,

- knowledge and decency,

- requirements and tastes,

- health

- It is important to know about good and bad habits (smoking, alcohol, drug addiction), misconduct, etc.

The main qualities of a bride are:

- Politeness

- kindness

- honesty

- sensitivity

- diligence

- responsibility

- good character

- ability to cook delicious food

- Do not lie

- care for her husband

- Respect mother-in-law as her own mother

Wise mothers, who have seen a lot in the country and become mothers of the country, say, «Treat your bride like a daughter, will your daughter be a bride?» The proverbs "A good bride is like your daughter, a good husband is like your son", "A good bride is like gold" (Larina, Naumova, 2008: 224). These sayings have too deep meaning. Such folk wisdom tells how to receive a new bride. That is why it is necessary to help yesterday's girl, today's young bride, to adapt to the new environment of housekeeping and mastery from the very beginning, to recognize the right and the left as soon as possible. The commandment of our ancestors "From the beginning of the wife, bring up the child from the age" was born out of such compassion and good intentions for the bride (Dobromyslov, 1900: 63).

Due to this adaptation from the beginning, due to changes in the social status of the former girl, the current bride, her behavior, actions, relationships, manner of her speech, style of clothes, etc. changes are made, their appearance as a girl is restricted and forbidden. The bride obeys the traditions of her ancestors. One of them is the ancient Kazakh tradition of naming brides without mentioning the names of their in-laws and ancestors, it is called "at tergeu". According to the established tradition, the bride usually gives her husband's older sisters such names as: Jakem, Atyteris, Arailym, Shyraylym, Zharkynym, Suluym, Bikesh; To his younger brothers: Myrza bala, Kenzhetai, Akzhigit, Myrza zhigit, Erkem, Aktore, Kishkenem. Even though the name of the object corresponds to the name of that relative, he also gives a conventional name. She considered it a sign of respect for her husband to call her husband's relatives by alternative names.

In the investigation of the name, which is rational and appropriate, the bride's ingenuity, knowledge of the world around her (eloquence in metaphors), intelligence, and even a good sense of humor are recognized. The custom of greeting the bride and groom with their parents and other people, who in the past called their husbands "the man of the house" and "the head of the family", is also one of the norms of mutual respect and prosperity between the bride and groom (Levshin, 1996: 32).

The bride's greeting (bowing) is the bowing and greeting of young brides to their parents with respect. The bride greets her parents every morning and when they come from a trip. Parents or other adults who get greeting of the bride say, "May you prosper!", "Be happy!", "Give birth toa son", etc. and express their gratitude. The bride greets not only in the Kazakh tradition, but also there are various ways of greeting.

Types of greetings of the bride - the bride bows in different situations. In some parts of Kazakhstan, such as Syr Darya, there are two types of greetings that are still intact, one is for brides to greet their husband's older brothers, and the other is for Kazakhs to greet after eating a meal (PMA). - 1). The tradition of greeting the bride begins with the betashar. Usually, the bride and groom bow down and greet each other after the betashar dedicated to each of her husband's close relatives. From the day the bride's face was opened and she stepped on the threshold, when the bride saw her husband's brothers, she crossed her arms on her knees in front of them, says "hello" "Salem berdik!" and bowed. Her husband's brothers greet her in the same way when they meet on the road. The elders respond to the bride's greeting with "do more", "be happy". This tradition symbolizes the bride's respect for her husband's brothers. The second kind of greeting is performed upon receive of the plate. When the eldest man at the table offers to take a plate after eating meat, the bride should greet him silently. Brides from Syr region are ready to receive a plate as soon as they feel that they finish eating, according to the traditions of the region. At the big feast, when food and divine food are served, the brides of the village line up one by one according to the number of plates served, and each of them bows and greets them. In the family, without a guest, they sit down and take plate after eating. This is due to the respect for the 
elders and the shanyrak, who consider meat dishes to be a great Kazakh dish.

There are many well-meaning actions, measures and customs associated with the adaptation of the bride to the traditions of the new environment and the formation of a new form, as well as prohibitions on actions to prevent evil (Levshin, 1996: 68).

Good rituals are performed from the moment the bride arrives. In the Kazakh's tradition there is a ritual connected with pouring oil to the fire by the belief of "Don't let the fire go out". When the bride enters the house for the first time, it is a good ritual to step on the right foot. On the contrary, it is superstitious to believe that leaning on your sideways is a sign of sadness and leaning on your jaw is a sign of grief, and this is prohibited as a sign of immorality. The abundance of superstitions and taboos against the bride is due to their educational value, and on the other, to the health of the expectant mother, the health of the offspring.

As for the bride's dress, the pattern of the dress that distinguishes the girl from the women, the customs and traditions of the brides are reflected in the features of their dress. According to the ancient tradition of the Syr region, the bride wear a dress with long sleeves. Brides did not go home without a headscarf. The tradition of brides not to go without a headscarf continues to this day. The information provided indicates that the cream of the Kazakh tradition along the Syr Darya has not yet been broken.

The bride's dress is one of the conditions that determine her social status in the new environment. They are - after saukele - "zhelek zhamylu", followed by "kimeshek". After becoming a bride, the bride, who has kept her saukele wrapped in a box which is called "sandyk", sometimes covers the "zhelek" until finds her first child, and in some places until she has 2-3 children. The zhelek is a type of ceremonial garment made of light purple fabric, which covers the whole body, forehead leaving only the face. At the appointed time, the bride "takes the flag and puts on a kimeshek" by slaughtering cattle, inviting the village elders and uncles. It is a ritual that marks a young, social initiative, which proves that the bride became a full member of this dynasty and became a mother, a faithful spouse, a housewife. The young bride wears a colorful, embroidered, beaded, and embroidered kimeshek.

Thus, mothers who have gone through life, who have had a lot of experience and fell in love with their grandchildren, have become influential in the village, and it is normal for men to do business, slaughter animals and invite guests.

There are many superstitions about the bride. The types of customs that make sense to the bride.
Such superstitions say that the bride should be safe from harm, slander, healthy offspring, luck, and so on. appearing from good intentions. The bride is offered "ultabar"in order to have a son. The motherin-law twists the bride's skirt to prevent an abortion. The mother puts in her pocket sweets or wrapped in a towel so that she can taste it when she returns from a party. (because if the bride wishes it, her problem cannot be returned, her breasts are swollen). When a young bride is invited as a guest or when she goes for a walk in the village, older women and grandmothers give her things like rings and earrings by saying "itayagyna sal". Later, when the woman gives birth, she puts the same things while washing the baby. After washing, they are shared by the local women as a ritual. This is called "Itayagyna salu" (Grodekov, 1889: 45). In order to avoid evil eye, on the carpet, and on the curtains an owl or an amulet is placed on the bride's bed.

When the bride enters a house in the village, she has to bend her knees and sit down, even if she is hurried. It is respect for the family, and on the other hand, it is believed that the cow will give birth. So when the bride or someone else tells something by standing and goes out of the house, the householder says, "Why don't you kneel down, do you want our cow give birth by standing?"

Some of the superstitions concerning the bride are as follows: If the bride's a state of fastidiousness, taste whims (in a pregnant woman) does not be full during the pregnancy, then water flows from the mouth of the child born from her; When the bride before giving birth empties the box (sandyk) at home, she will give birth quickly; If a person's leg on the side where the bride is sitting is numbed, it is interpreted that the bride is pregnant; As the day of the bride's birth approaches, she walks barefoot, saying, "Mother Earth, give me strength"; a pregnant woman or the woman who gave birth must not go to the river at night; The pregnant bride does not hold such objects as knife, scissors and hacksaw as she will give birth prematurely; When the bride is unable to give birth, a sword is played on her head, a stallion is tied around her waist, salt is thrown into the fire, men enter the house, slap her skirts with both hands, and sometimes shoot a gun; if someone puts freshly boiled soap on top, then new coming bride will be arrogant; the threshold of the housesmears with oil so that the family's table will be plentiful; If the bride gathers up thefurnace in the house, the husband will fall in love with another woman; in order to get rid of evils "arasha" smoke is used; If she doesn't give the "bride's tongue" "kelin tili" as a souvenir, the girl will bumble; if the young bride's breasts swell, the dead man is washed gloves 
covered; the bride gives birth to many children at the birth of the new moon; If two young people have a lot of stars on their wedding night, they will have many children (Haruzin, 1888: 45).

Prohibitions related to the bride - actions, movements, gestures that the bride should not do. Such prohibitions are imposed to protect the bride from bad superstitions. There are two types of prohibitions against the bride: one is the ban on the bride's personality (the bride does not sit on her parents-in law' bed, all the time she has to wear a headscarf, etc.), and the other is the prohibition of other people, young and old, to be on the alert from bad superstitions. (it is prohibited another woman sit on the bride's bed because they are afraid that woman will do a bad ritual. ; if a woman who can't have a baby will sit on the new coming bride's bed, it is believed that she will have a baby soon, however, a new coming bride will have less babies, that is why, they did not used to do t; adults do not speak rudely in front of the bride, etc.) (Kittary, 1889: 211).

Due to ancient superstitions, Kazakh brides try to avoid certain things and try to avoid them, and these superstitions still exist. The bride does not laugh inappropriately; does not cross in front of adults; does not call the names people older than her; does not look inside the curtain where strangers are sitting; does not sit on someone's bed; does not pour dirty water on the walkway; does not speak loudly among crowded people; does not stand while others are working; inside the village, the bride walks outside the yurt; does not speak against his parentsin-law; enters the house with the right foot; does notgo to the toilet in a barn or in a collapsed house; the bride does not walk without headscarf; does not cross the dishes, rope, shanyrak, hat, Koran; does not look at the sun, the moon, the graveyard, the village and go to the toilet on the road; ; do not run in or out of the house; does not itch in public; does not lean sideways; does not go beyond customs and manners; does not call"mybaby" in front of parents-in-law, says "the child of grandparents"; does not lie, gossip; does not look at someone's barn, does not beat the baby at the breast; young brides do not sit in the place of honor if there is elder people; does not stare at anyone's face; the bride does not doubt her mother's words; does not sit in front of a person, sits on one side; Kazakh brides do not name their husbands and do not argue with them; the bride does not go to her parents housetill one year; when driving a car, she does notwalk in the cross section in front of the car, she passes behind; the bride does not speak loudly in front of parents, elders, in-laws; adults usually do not look at young bride; when the guest arrives, the bride does not sweep the house, shout at her child or anyone else; The pregnant bride does not eat camel meat. It is believed that if she eats, she will carry her baby like a camel for a long time and will not be born on time. If the baby is notforty days yet, she must not throw ashes on the bride's house at night. A young woman, who gave birth must not say to go away to the dog, so she loses her teeth; a pregnant woman or a young woman who gave birth does not go to the river at night; If the bride is pregnant, she must not hold a needle or thread, thinking that the child will return to the umbilical cord at birth; It is believed that the bride does not eat rabbit meat when she is pregnant, because her child will be cowardly as a rabbit (Krasnov, 1887:63).; it is said that the a pregnant bride does not jump on the rope, but if she does, the baby's umbilical cord will be wrapped around her neck; does not sweep the house at night, does not pick up nails; on Friday she does not do laundry because the ghosts are offended; the surface of the water and food in the container must not be opened; does not re-export the fuel brought into the house; a pregnant woman does not eat "tolarsak", because it will be hard for her to give birth; the bride and her husband must not have a sexual contact at dawn, at sunset, at the eclipse of the sun or the moon, because it is believed that the child will born with defect; does not borrow water or lend water; does not step on the ash, the feet of the person who steps on them numbs; she does not blow out the lamp because she will be forgetful; she must not pour white things on the ground, Animals are not tied with rope, the bride must not speak before elders speak (Levshin, 1996: 105).

\section{Conclusion.}

Nowadays, the attitude to the bride is not traditional in Kazakh society. There are many other prohibitions that young brides take into account (Grodekov, 1889: 88 ). Many of them depend on traditional society. The Kazakh people are very rich in traditions. Not only Kazakhs, but any nation has its own customs, rituals and way of life. You can also learn about the culture of the country from their own traditions. And the national tradition of the rich Kazakh people - investigation of the name "at tergeu" - seems to be forgotten today. Thus, tradition speaks so, that our tradition will live forever in our minds.

According to the national tradition, brides do not name their grandfather, father-in-law, sister-in-law, but give them a proper name: "Mr. brother-in-law", "rich grandfather", and so on. Also for a woman, "White grandmother", "syrgalym", "shashbaulym", "kulymkozym". They could put any funny names. For example, for short stature is called "sungagym", for those who walks slowly is called "zhuyrigim" 
(who walks fast). All of this is truly a sign of respect and esteem. Such actions are not part of the bride's etiquette. In the Kazakh tradition, the use of actions that signify a happy situation (for example, throwing the turban in the air, slapping the back, etc.) is considered a bad superstition and is not allowed to be repeated. Some superstitions and prohibitions are also found in proverbs.

\section{References}

Abashin, S.P. (2001). Chaj v Srednej Azii: Istorija napitka v XVIII - XIX. // Tradicionnaja pishha kak vyrazhenie jetnicheskogo samosoznanija. - M., $156 \mathrm{~s}$.

Argynbaev, H. (1962). Kratkij ocherk material'noj kul'tury pereselencev iz Rossii v Kazahstan: po materialam Vostochnogo Kazahstana, vtoraja polovina HIH- nachalo HH veka // Voprosy jetnografii i antropologii Kazahstana. - Alma-Ata.

Dobromyslov, A.N. (1900). Turgajskaja oblast'. Istoricheskij ocherk. - Orenburg. - Vyp. 1. - S. 33, 111.

Gurulev, S.A. (1996) Chaj po-sibirskij. // Chaj v Sibiri. - Irkutsk. - S 16.

Grodekov, N.I. (1889) KirgizyikarakirgizySyr-Dar'inskojoblasti. T.1. Juridicheskij byt.. Tashkent: Tipo-Litografija S.I. Lahtina.

Haruzin, A.N. (1888). Stepnye ocherki (Kirgizskaja Bukeevskaja orda). Stranichki iz zapisnoj knigi. - M.,- S. 69, 74, $115,143$.

Kittary, M.Ja. (1849). Kirgizskij tuj // Zhurnal ministerstva vnutrennih del. - SPb., - Ch. 25. - S. 34.

Krasnov, A.N. (1887). Ocherki byta Semirechinskih kirgizov // Izvestija IRGO. - SPb., - T. 23. - Vip, 4.

Larina, E.I. Naumova O.B. (2008). Tradicija chajpitija u kazahov // Hmel'noe i inoe: napitki narodov mira (otv. Red. S:A. Arutjunov, T.A. Voronina). - M.: Nauka, - S. 221-248.

Levshin, A.I. (1996). Opisanie kirgiz-kazach'ih ili kirgiz-kajsackih ord i stepej. - Almaty. - S. 306.

Meirmanova, G.A. (2009). Kul'tura obshhenija u kazahov: transformacija tradicionnogo jetiketa: Avtoreferat dis. ... k.i.n. - M.,-$24 \mathrm{~s}$.

Nebol'sin, P. (1850). Zametki na puti iz Peterburga v Barnaul. - SPb., - S. 178, 179.

Nebol'sin, P. (1835). Statisticheskie zapiski o vneshnej torgovle Rossii. - SPb., - Ch. I. Gl. 2. - S. 173;

Potanin, G.N. (1868) Okaravannoj torgovle s dzhungarskoj Buhariej v HVIII stoletii. - M.

Pohlebkin, V.V. (2000). Chaj. Ego tipy, svojstva, upotreblenie. - M.,. - S.9. 